Original Research Paper

\title{
Weed Management in Sesame Field (Sesamum indicum L) Using Wheat Straw and Tillage or no Tillage Systems
}

\author{
${ }^{1}$ Srra'a Nsayef Muslim Al-Eqaili, ${ }^{2}$ Nabil Raheem Lahmod and ${ }^{3}$ Oda Hassuni Eshkandi \\ ${ }^{1}$ Department of Geophysics, College of Geophysics and Remote sensing, University of Karkh, Baghdad, Iraq \\ ${ }^{2,3}$ Department of Agronomy, College of Agriculture, University of Wasit, Wasit, Iraq
}

Article history

Received: 18-11-2015

Revised: $18-11-2016$

Accepted: 29-03-2017

Corresponding Author: Nabil Raheem Lahmod Department of Agronomy, College of Agriculture, University of Wasit, Wasit, Iraq Email: n.raheem@yahoo.com

\begin{abstract}
A field trial was achieved to test the response of weed and sesame crop to use wheat straw and tillage or no tillage systems. The experiment treatments were include; no tillage without straw, tillage without straw, tillage with straw, incorporated with soil and straw as cover crop (no tillage). The result shown that weed density and biomass have high significantly suppression when wheat straw applied as cover crop and without tillage soil compared with soil tillage without straw treatments, while no significant different noticed between treatment that no tillage without straw and tillage with straw incorporated with soil treatments. Using wheat straw as cover crop significantly improved sesame yield and yield components about 50\% more than using wheat straw as incorporated with soil treatment and no tillage without straw treatment. This increase in sesame yield can be attribute to amended of capsules number per plant (53.2 capsules) and number of seed per capsule (54.6 seed) compared with 18.1 capsules per plant and 53.6 seed per capsule in tillage without straw treatment. The results of this study have led to the conclusion of possibility using wheat straw hopeful approach to amended sesame planting when used as cover crop.
\end{abstract}

Keywords: Wheat Straw, Allelopathy, Weed, Tillage System, (Sesamum indicum $\mathrm{L}$ )

\section{Introduction}

Weeds are serious pest damage for the most crops caused by competition on light, nutrients, moisture and space and this lead to enormous reduction in crop yield (Lahmod and Alsadaawi, 2014). The application of herbicide to weeds control has been a major factor enabling the intensification of agriculture, however, the excessive using of herbicide will be increasing herbicide resistance in weeds and extensive concern about adverse environmental effects (Stephenson, 2000). Additionally, highly costs for weeds management and agricultural production. To avoid these problems, it has been suggest a new approach of weed control which can be inexpensive, easy and helpful in maintaining the ecosystem and biodiversity (Alsaadawi and Dayan, 2009; Lahmod and Alsaadawi, 2014). There are many weed management techniques that can be lead to reduced herbicide dependence, as direct-seeding, competitive varieties, increased seeding rates, strategic fertilizer placement, growing silage and cover crops, all these have excellent potential to suppress weed growth (Harker and Blackshaw, 2009). Crop residues hold a great prospect for meeting some of those demands and have more readily applicable in agro ecosystems (Alsaadawi et al., 2013; Testa et al., 2014; Sgroi et al., 2014). This approach (Crop residue) can be used in weeds management by two ways; it can be used by selecting an appropriate residue of crop variety then incorporating it in soil, Also it can used by applying residues or straw as mulches on soil surface in a rotational sequence that allows residues to remain in the field (Alsaadawi and Dayan, 2009). However, each of the above has possible strategies. The crop residues are the most successful, effective and readily available (Lahmod, 2012; Clark, 2012; Spiertz, 2013). The cover crop is a one of strategies which can be suppressive weed and enhance of yield without environmental pollution as a secure approach to the world's food supply for future of generations (Finney and Creamer, 2008). Crop residue have been provide a maintained of agro ecosystem through lessening of erosion, water conservation saving, increase biological diversity (e.g., microbes, insects and birds), increase nutrient cycling and biological nitrogen fixation, increase soil organic matter and improve weed control (Hoffbeck et al., 2008; Clark, 2012) and increase 
crop yields, therefore, using wheat residue (straw) as a mulch or incorporate in soil can be helpful to weed control of sesame crop and enhancement of seeds yield. In order to assess that this study was done.

\section{Materials and Methods}

\section{Site Description}

The proposed study was conducted at Research Farm of Biological science Department, College of Science, University of Baghdad, Baghdad, Iraq (33.2 N latitude and $44.22 \mathrm{E}$ longitude, $30 \mathrm{~m}$ above sea level). The soil of experimental site was calcareous silt clay loam. Organic carbon, $\mathrm{pH}$ and EC were $0.8 \%, 7.8$ and $3.0 \mathrm{dS} \mathrm{m}$, respectively. The average annual rainfall is less than 50 $\mathrm{mm}$ and day/night temperatures during the growing season were $30-40 / 15-30^{\circ} \mathrm{C}$.

\section{Prepare Straw of Wheat Plants}

To prepare straw of wheat plants, field plot $(24 \times 2 \mathrm{~m})$ by four replicates were tilled twice in the first of November 2012 in the Research Field of Biological Department. Grains of wheat cv. Abu-Grab were manually sown in all plots in $20 \mathrm{~cm}$ apart crop rows at seed rate of $120 \mathrm{~kg} \mathrm{ha}^{-1}$. Urea as Nitrogen fertilizers $(46 \% \mathrm{~N})$ and triple super phosphate $\left(46 \% \mathrm{P}_{2} \mathrm{O}_{5}\right)$ were applied to these plots which recommended for wheat crop and irrigation were applied as recommended for this crop. At the maturity stage, Biological yield of wheat crop was harvest at $30 \mathrm{~cm}$ from stem height and left the straw on the soil surface. After harvesting stage, plots were subdivided into plots measuring $8 \times 2 \mathrm{~m}$ as experimental treatments. The half of these plots were removed wheat straw while the other half were left on soil surface. Half plots that received straw and remove straw were tilled at mid of June 2013 by using a disc plough to incorporate with the soil. While, the other half were left without tillage. Fertilizers Nitrogen as urea $(46 \% \mathrm{~N})$ and phosphorus as triple super phosphate $\left(\begin{array}{ll}46 \% & \mathrm{P}_{2} \mathrm{O}_{5}\end{array}\right)$ were applied to these plots as recommended for sesame crop. Seeds of sesame was sown in $60 \mathrm{~cm}$ spaced crop rows with $20 \mathrm{~cm}$ among beds of seeds. All plots received equal irrigation water during the entire course of study. The experimental treatments were the following:

1. No tillage without straw

2. Tillage without straw

3. Tillage with straw incorporated with soil

4. Straw as cover crop (no tillage)

\section{Measurement of Traits}

The traits measured were weed density (plant. $\mathrm{m}^{-1}$ ), weed biomass $\left(\mathrm{g} . \mathrm{m}^{-1}\right)$, plant height, number of branching, number of capsules per plant, number of seeds per capsule, 100-seed weight and yield (t.ha $\left.{ }^{-1}\right)$.

\section{Results \\ Weed Growth}

Weed flora was dominated the experimental site during growth season comprised of Echinochloa colonum (L) Link, Cyperus rotaundus L., Portulaca olerace $\mathrm{L}$ and Cyndon dactylon. The weed density and biomass were high significantly suppression noticed when wheat straw applied as cover crop without tillage soil compared with treatments that tillage without straw, while not significant different noticed between treatment that no tillage without straw and tillage with straw incorporated with the soil treatments. Wheat straw as cover crop without tillage system reduced weed density to

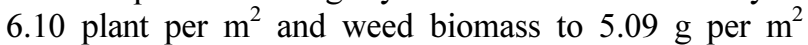
compared with 30.33 plant per $\mathrm{m}^{2}$ (weed density) and $89.89 \mathrm{~g}$ per $\mathrm{m}^{2}$ (weed biomass) that showed in tillage system treatment and without wheat straw. The incorporation of wheat straw in soil reduced weed density

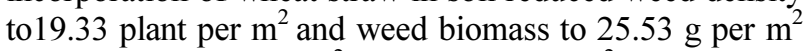
while 21.67 plant per $\mathrm{m}^{2}$ and $35.71 \mathrm{~g}$ per $\mathrm{m}^{2}$ weed density and weed biomass respectively) reduction was noticed when soil no tillage without straw as shown in (Table 1).

\section{Plant High and Number of Branch in Sesame}

No significant different in plant high was noticed in all treatment However, showed increased by $17 \%$ when straw applied as cover crop without tillage compared with straw when incorporated with soil. The Number of branches per plant of Sesame were recorded highest increased when wheat straw was applied as cover crop (no tillage) treatments. While these branches were the lowest when tillage soil without straw treatments (Table 2).

\section{Sesame Yield and Yield Components}

Using wheat straw as cover crop improved sesame yield significantly and yield components about 50\% more than using wheat straw as incorporated in soil treatment and no tillage without straw treatment, while the lowest sesame yield by $75 \%$ less than wheat straw as cover crop without tillage (Table 3). However, yield and yield components were lowest in treatment that was tillage without straw presumably due to high weed pressure in terms of weed density and dry biomass that was noticed (Table 1) in this treatment. The advance increase raise of sesame yield in straw as cover crop (no tillage) was due to high number of capsules per plant (53.2 capsules) and number of seed per capsule (54.6 seed) compared with 18.1 capsules per plant and 53.6 seed per capsule in tillage without straw treatment. A bigger weight of 100 seed was recorded in straw incorporated in soil and straw as cover crop (no tillage) treatments. 
Table 1. Weed density and Weed biomass after different wheat straw treatment with sesame crop

\begin{tabular}{lcc}
\hline Treatment & Weed density $\left(\right.$ plant. $\left.\mathrm{m}^{-1}\right)$ & Weed biomass $\left(\mathrm{g} . \mathrm{m}^{-1}\right)$ \\
\hline No tillage without straw & 21.67 & 35.71 \\
Tillage without straw & 30.33 & 89.89 \\
Tillage with straw incorporated with soil & 19.33 & 25.53 \\
Straw as cover crop (no tillage) & 6.33 & 6.05 \\
L.S.D 0.05 & 6.10 & 5.09 \\
Cv & 15.70 & 6.50 \\
\hline
\end{tabular}

Table 2. Plant high and number of branches to sesame crop under different wheat straw treatment

\begin{tabular}{lll}
\hline Treatment & Plant high $(\mathrm{cm})$ & Number of branches per plant \\
\hline No tillage without straw & 151.2 & 2.330 \\
Tillage without straw & 163.8 & 0.670 \\
Tillage with straw incorporated with soil & 148.2 & 2.080 \\
Straw as cover crop (no tillage) & 178.9 & 4.330 \\
L.S.D 0.05 & NS & 0.891 \\
Cv & 8.7 & 19.100 \\
\hline
\end{tabular}

Table 3. Yield and yield components of sesame crop under different wheat straw treatment

\begin{tabular}{llllc}
\hline & $\begin{array}{l}\text { Number of } \\
\text { capsules per plant }\end{array}$ & $\begin{array}{l}\text { Number of } \\
\text { seed per capsule }\end{array}$ & $\begin{array}{l}\text { Weigh of } \\
100 \text { seed }(\mathrm{g})\end{array}$ & $\begin{array}{l}\text { Yield of } \\
\text { seeds }\left(\mathrm{kg} . \mathrm{ha}^{-1}\right)\end{array}$ \\
\hline No tillage without straw & 26.00 & 69.10 & 0.22 & 495.7 \\
Tillage without straw & 18.10 & 53.60 & 0.25 & 297.3 \\
Tillage with straw incorporated with soil & 23.30 & 43.70 & 0.34 & 452.5 \\
Straw as cover crop (no tillage) & 53.20 & 54.50 & 0.32 & 1184.1 \\
L.S.D 0.05 & 9.41 & 15.27 & 0.01 & 217.8 \\
Cv & 18.00 & 13.80 & 2.40 & 18.0 \\
\hline
\end{tabular}

\section{Discussion}

The results on this study shown that using wheat straw as cover crop with no tillage soil system improve yield and yield component of sesame. This amended in yield can be justified to the lowest weed density and suppression growth it (Table 1), following, that will be decrease the competition between crop and weeds on space, water and nutrient in soil. The present wheat residue (straw) on soil surface as cover crop can be prevent sun light (radiation) to reach weeds seedling in field, as well as, released some of allelopathic compounds from wheat residue which can be suppression weed seed growth in soil (Roth et al., 2000; Clark, 2012). Tillage the soil increased weed growth because present high seed number of weed in soil (soil seed bank) that can be exit in to soil surface by tillage. Incorporated of wheat straw in soil perhaps suppression some weeds caused by released allelocimicals component from residues (Lahmod and Alsaadawi, 2014). Nevertheless, these components do not along stay because decomposing and leaching it from soil depth of which can be caused recurrent weed growth and competition of crop in next time (Lahmod, 2012). In addition to lowest weed competition, wheat residue can be keeping of soil moisture and assist of available soil nutrient (Finney and Creamer, 2008). All these factors were contributed of enhance sesame growth (Table 2) and increased number of capsules per plant and number of seed per capsules which caused by positive increased of seed yield sesame per hectare (Table 3).

\section{Conclusion}

From these results, it can be conclude the possibility of using wheat straw as hopeful approach to amended sesame planting when used as cover crop.

\section{Acknowledgement}

I would like to thank Department of Biology, College of Science, University of Baghdad, to prepare a field, and thank all colleagues: Dr. Saraa N.M. Eqaili, which supervised the field data and Assist Prof Oda Hassuni Eshkandi who contributed to the field working and contributed to financially support research. Thank to Mr. Muhammad K. Altai to coordinated the mouse work. Thank to reviewers for their good notes.

\section{Author's Contributions}

Srra'a Nsayef Muslim Al-Eqaili: Application of field experiment and record data and contributed to the writing of the manuscript.

Nabil Raheem Lahmod: Designed the research plan and field experiment, analysis of data and writing of the manuscript.

Oda Hassuni Eshkandi: Contributed by some field working and funding of research.

Muhammad K. Altai: Coordinated the mouse work. 


\section{Ethics}

This article is original and contains unpublished material. The corresponding author confirms that all of the other authors have read and approved the manuscript and no ethical issues involved.

\section{Reference}

Alsaadawi, A.S. and F.E. Dayan, 2009. Potentials and prospects of sorghum allelopathy in agroecosystems. Allelopathy J., 24: 255-270.

Alsaadawi, I.S., A. Khaliq, N.R. Lahmod and A. Matloob, 2013. Weed management in broad bean (Vicia faba L.) through allelopathic Sorghum bicolor (L.) Moench residues and reduced rate of a pre-plant herbicide. Allelopathy J., 32: 203-212.

Clark, A., 2012. Managing Cover Crops Profitably. 3rd Edn., DIANE Publishing, ISBN-10: 1437903797, pp: 248.

Finney, D.M. and N.G. Creamer, 2008. Weed management on organic farms. North Carolina State University, North Carolina A \& T State University and the North Carolina Department of Agriculture and Consumer Services.

Harker, K.N. and R.E. Blackshaw, 2009. Integrated cropping systems for weed management. Prairie Soils and Crops.

Hoffbeck, C., J. Ruhland, J. Miller and J. Millar, 2008. Benefits of cover crops in no-till wheat stubble. Pioneer Agronomy Sci. Field Fsct., 8: 1-4.
Lahmod, N.R. and I.S. Alsaadawi, 2014. Weed control in wheat using sorghum residues and less herbicide. Allelopathy J., 34: 277-286.

Lahmod, N.R., 2012. Allelopathic effects of sorghum (Sorghum bicolor L.) Moench on companion weeds and subsequence crop. PhD Thesis, Field Crop Sciences College of Agricultural, University of Baghdad, Iraq.

Roth, C.M., P.S. James and M.P. Gary, 2000. Allelopathy of sorghum on wheat under several tillage systems. Agron. J., 92: 855-860. DOI: 10.2134 /agronj2000.925855x

Sgroi, F., A.M. Di Trapani, R. Testa and S. Tudisca, 2014. Economic sustanaibility of early potato production in the mediterranean area. Am. J. Applied Sci., 11: 1598-1603. DOI: 10.3844/ajassp.2014.1598.1603

Spiertz, H., 2013. Challenges for crop production research in improving land use, productivity and sustainability. Sustainability, 5: 1632-1644. DOI: $10.3390 /$ su5041632

Stephenson, G.R., 2000. Herbicide use and world food production: Risks and benefits. Proceedings of the Abstracts of the 1st International Weed Science Congress, Jun. 6-11, Do Iguassu, Brazil, pp: 240-240.

Testa, R., A.M. Di Trapani, F. Sgroi and S. Tudisca, 2014. Economic sustainability of Italian greenhouse cherry tomato. Sustainability, 6: 7967-7981.

DOI: $10.3390 /$ su6117967 